\title{
James S. Clarkson and Theodore Roosevelt, 1901-1904: A Study in Contrasting Political Traditions
}

David Crosson

THEODORE ROOSEVELT BECAME PRESIDENT in 1901 by accident, and no one was more aware of that fact than Theodore Roosevelt. He had reached the pinnacle of political success while still a young man, but the former Rough Rider demanded more than success by accident; he sought the struggle and exultation of personal triumph. He looked with exhilaration toward the election of 1904. In the process of gaining election he would have to cajole the aging sages of Republican orthodoxy, some of whom had been in politics longer than the young Chief Executive had lived. With these still resilient and powerful men Roosevelt had to build an organization to insure himself his party's nomination before he could hope to gain public approval."

James S. "Ret" Clarkson of Iowa and New York exemplified the Republican stalwart in 1901. Although he had never held public office, as a founder and a president of the National Republican League, first-assistant Postmaster General under President Benjamin Harrison, and a former vice-chairman of the Republican National Committee he had once been a significant force in establishing Republican party policy and campaign techniques. A vehement opponent of civil service reform and a staunch defender of the spoils system of political patronage, Clarkson represented old, Radical Republicanism in its purest form. In both his previous career and his often ambiguous relationship with the young

'John Morton Blum, The Republican Roosevelt (2nd ed., New York, 1970), pp. 8, 27.40. 
man in the White House, James S. Clarkson offers a unique portrait of one of the two conflicting Republican traditions at the turn of the century. Clarkson personified the old Radical Republican ethic, in contrast to the new, merchandized, middle-class morality of the civil service reformers, emerging Progressivism, and Theodore Roosevelt. ${ }^{2}$

Early in Roosevelt's first term a fortuitous combination of a vacant position, an available candidate, and the immediate response of the two Iowa senators to fulfill mutual obligations to an old friend resulted in the political reactivation of James S. Clarkson's career. In the second week of April 1902 the surveyor of the Port of New York died. The two Hawkeye senators, venerable William Boyd Allison and eloquent Jonathan P. Dolliver, immediately recognized the possibilities of the vacant position. As general supervisor of the boarding of arriving ships and the inspection of their cargoes, the surveyor was the chief lieutenant of the collector of the port. The position therefore held significant dignity to satisfy Clarkson's sensitive ego. It would also place him in direct contact with the laborers of the port as superintendent of all weighers, measurers, and gaugers. This was the type of situation and level of organization in which he was politically most effective. Finally, the duties were sufficiently ambiguous and flexible to allow Clarkson as much time as he desired for his continuing political machinations. The senators went to work immediately to secure the appointment and satisfy their mutual obligations. ${ }^{3}$

By 1900 the dean of the Senate, Allison, owed much to the old friend who had helped him secure his first senatorial election thirty years before. To him fell the task of persuading New York's "easy boss," Senator Thomas C. Platt, to accept the 1902 appointment. In recognition of his political acumen and his magnificent set of lungs, Dolliver had been appointed to the Senate in 1900 , and he was equally indebted to Clarkson. He had the job of convincing Roosevelt. Allison cornered Platt at 49 Broadway and

${ }^{2}$ Stanley P. Hirshson, “James S. Clarkson and the Civil Service Reformers, 1889-1893," Iowa Journal of History, 57:267-278.

'John Dean Goss, $A$ History of Tariff Administration in the United States from Colonial Times to the McKinley Administration Bill (New York, 1897), pp. $25,29$. 
received his commitment. Then both senators went to Roosevelt. On April 14, before the recently deceased surveyor had been buried, the White House secretaries "leaked" the news of Clarkson's appointment to the press. "It was a funny situation," wrote Dolliver. "If Roosevelt had known that Platt was anxious to help you it probably would have queered it. If Platt had known that Roosevelt was right on you, he would have had his doubts about it." On April 17 the Senate unanimously confirmed the appointment. ${ }^{4}$

The appointment elicited immediate objections from those whose memories went back ten years to Clarkson's career as postal department "headman." Perplexed by the "amazing and imcomprehensible" appointment, the New York Times suggested that "it would have been better to abolish the office." Sensitive to the attacks, and well aware of Clarkson's past record, Roosevelt directed the new surveyor "to be particularly careful not to get into any conflict with the Civil Service Commission." The Times reasoned that "the President is 'hunting delegates,' and that he is doing so with ineptitude quite inconsistent with his previous action." $s$

Clarkson knew of the efforts being made in his behalf and appreciated them. The kindness of old friends eased the long days and nights at the bedside of his gravely ill son. The courage that President Roosevelt displayed in making the appointment, "knowing it will be abbased [sic]," especially moved him. But he still remembered Civil Service Commissioner Roosevelt's chastisement of spoilsman Clarkson in 1891. Roosevelt then thought that the "headsman's" arguments against reform were "the very best

${ }^{4}$ Leland L. Sage, William Boyd Allison (Iowa City, 1956), p. 284; James Otis Wheaton, "The Genius and the Jurist: A Study of the Presidential Election of 1904" (unpublished Ph.D. dissertation, Stanford University, 1964), p. 567. Dolliver to Clarkson, April 14, 1902, quoted in Wheaton, "Genius," p. 567; New York Times, April 15, 1902.

${ }^{5}$ New York Times. April 15, 16, 18, 20, 1902; "At the White House," Washington Evening Star (hereafter referred to as the ATWH), April 14, 1902, Theodore Roosevelt Papers, Manuscripts Division, Library of Congress (hereafter referred to as LC); William Dudley Foulke, Fighting the Spoilmen: Reminiscences of the Civil Service Reform Movement (New York, 1919), pp. 154-155; The Nation, 74:318; The Outlook, 70:988-89, 71:3-4; Roosevelt to Clarkson, May 5, 1902, Elting Morison, ed., The Letters of Theodore Roosevelt (8 vols., Cambridge, 1951), III, p. 256. 
argument for it." The two exchanged friendly correspondence shortly after the incident, but the old politician still questioned the depths of Roosevelt's affability, and Clarkson psychologically required devoted, personal friendship. Both Dolliver and Roosevelt took pains to hearten him. Dolliver reassured his former patron that the President "believes in you and wants to be your friend. . . " By mid-May his old enthusiasm returned with his son's health, and Clarkson entered the New York Customs House with a convincing devotion to the man who had appointed him. ${ }^{6}$

That man was perplexed in 1902 by a problem that Clarkson had known intimately as first-assistant Postmaster General-the Republican party in the South. But the voice of the realistic twentieth-century politician, not that of the Reconstruction Radical, dominated Roosevelt's southern strategy. Instead, the surveyor's activity, especially after November 1902, centered upon the two other areas in which he maintained an active interest: New York and the West (particularly Iowa). Clarkson's activity in New York especially exemplified his three important characteristics as a politician: his continual devotion to Roosevelt, despite the President's obvious hesitation in the South, his penchant for conspiracies, and his very real ability as a "grass roots" political organizer. ${ }^{7}$

The political situation in New York deteriorated precipitously for the Republican party after Roosevelt's move to Washington in 1901.Benjamin Barker Odell, for years Thomas Platt's trusted lieutenant, and the anointed Governor of the Empire State, declared open warfare upon his mentor and was not satisfied until he had wrested complete control of the party organization from the Easy Boss. Platt's stature as a national politician rested not in federal legislation or in the management of national conventions, but in his complete control of the New York State legislature. His greatness was "not in Washington, but in Albany." Governor Roosevelt had not cared to replace Platt as sole proprietor of the

'Clarkson to Allison, April 7, 17, May 2, 1902, William Boyd Allison Papers, Iowa Department of History and Archives, Des Moines (hereafter referred to as IDHA); Clarkson to Roosevelt, April 27, 1902, Roosevelt to Clarkson, May 3, 1902, Roosevelt Papers, LC; Roosevelt, quoted in the New York Times, May 20, 1891; Dolliver to Clarkson, April 14, 1902, quoted in Wheaton, "Genius," p. 267.

'Wheaton, "Genius," pp. 191-192, 192-194. 
New York machine. Governor Odell did, and Platt had personally provided an invaluable apprenticeship. By the end of 1901 the old man, whose skin now envinced "the yellow parchment of senility," was "passing very gently from his kingdom and his power."8

Although admiring Odell's aggressiveness and political acumen, Clarkson instinctively aligned with Platt. They shared a healthy appreciation of the importance of personal reward in the establishment and maintenance of a vital political organization. To both men, discipline maintained the fidelity of individual devotion, and, if all individuals were "taught to consider that there is not only public but personal advantage to be gained, they will work. ..."9 Clarkson had worked for years with Thomas C. Platt, and in 1902 was rewarded with the Senator's acquiescence to his appointment as surveyor. He could not then abandon Platt in his time of adversity. ${ }^{10}$

The effects of the New York struggle, not the participants, concerned Theodore Roosevelt. The conflict over naming Odell's running-mate in 1902 threatened the President's desired endorsement for re-election by the state convention. Although Clarkson served as a messenger between Roosevelt and the two protagonists, he was not a significant influence. Roosevelt used him to present the endorsement resolution to the New York leaders, who gathered on September 29 to debate their differences, but Clarkson was chosen because of his availability, rather than his influence. Recognized for both his devotion to Platt and his equal fidelity to Roosevelt, the surveyor represented the best efforts of harmony and the desire to unite in common accord behind the state's favorite son. Collector of the port, Nevada N. Stranahan, rather than Clarkson, directly represented the President in the infighting of New York's Republican leadership. After the September 1902 meeting Clarkson never again acted in behalf of the Administration with the political elite of the Empire State. ${ }^{11}$

'Review of Reviews, 22:687; William Allen White, "Platt," McClure's Magazine, 18:148, 153.

${ }^{9}$ Clarkson to T. L. Michener, May 29, 1890, quoted in H. Wayne Morgan, From Hayes to McKinley: National Party Politics, 1877-1896 (Syracuse, 1969), p. 331.

${ }^{10}$ Thomas C. Platt, The Autobiography of Thomas Collier Platt (New York, 1910), pp. 499-500, 501, 502-503.

"Roosevelt to Clarkson, Aug. 16, 1902, Nevada N. Stranahan to Roosevelt, 
Instead, he provided the President with political intelligence on the business and financial interests of New York City, with which he had continual contact as surveyor, and organized the city's laborers and ethnic groups behind the President. This was a job that was important for the success of Theodore Roosevelt in the 1904 general election.

Clarkson's reports on the business community tended to emphasize conspiracies behind every investor's desk. Roosevelt, also amenable to conspiracy theories, agreed with the surveyor's analysis that the "criminal rich" were "trying secretly to organize against me. ..." He was further convinced that they were "endeavoring to push Hanna into the leadership of the opposition." 12

Although he was convinced of a conspiracy, Clarkson was not as positive that Hanna was the foil. Admitting that the Ohio senator had indicated "a willingness to be unfriendly to the President if the opportunity should offer, and give him sufficient encouragement," Clarkson also took careful note that "he talks on the inside and among friends of Roosevelt as though he looks for nothing else than for the President to be nominated by acclama. tion. ..." It appeared to Clarkson that "no two men are farther apart than they," and that there was a "jointless attempt at organization ... among the Hanna people," but that Hanna, himself, declined to either lead or participate in the movement. ${ }^{13}$

If Clarkson remained skeptical of Hanna's complicity in a conspiracy of businessmen and financiers, he continued adamant in his belief that such a conspiracy did in fact exist. The plot consisted of many different cabals, innumerable coups, and an often changing membership, but it remained continually insidious in purpose. According to one particularly devious plan, John D. Rockefeller and George Gould were preparing to construct and control a continuous railroad system from the Atlantic to the $\mathrm{Pa}$ -

Dec. 9, 1902, Roosevelt to Stranahan, March 26, 1903, Hamilton Fish to Roosevelt, March 21, 1904, Roosevelt Papers, LC: Roosevelt to Benjamin Barker Odell, Feb. 1, 1904, Morison, Letters, IV, pp. 714-715, III (editor's note), pp. 328-329.

${ }^{12}$ Roosevelt to Clarkson, May 27, 1903, Roosevelt Papers, LC.

${ }^{13}$ T. L. Michener to Clarkson, Oct. 15, Nov. 12, 13, 1902, March 12, 1903 , Clarkson to Leigh Hunt, Nov. 17, 1903, James S. Clarkson Papers, LC; Clarkson to Hunt, Dec. 8, 1903, James S. Clarkson Papers, IDHA. 
cific, which would control the political machinery in every state through which it passed. James J. Hill, according to Clarkson, proposed to co-operate by controlling the Pacific Northwest through his cumulative railroad interests. Their candidate was to be Democratic Senator Arthur P. Gorman of Maryland, who would win control of the states via the railroads. In addition, so the theory went, he would receive the votes of Rhode Island, through the duplicity of Senator Nelson A. Aldrich, and West Virginia, because the wife of the state's Republican senator was Gorman's cousin. ${ }^{14}$

Through 1903 and 1904 Clarkson continually warned of conspiracy. Involving first one financier and then another, implicating sundry political hopefuls, and perceiving any number of combinations of moneyed power, he ultimately determined that the unadultered "angry millionaires" were backing Judge Alton B. Parker for the Democratic presidential nomination, and the reform millionaires were supporting former President Cleveland. When, by October 1904, it appeared that a substantial number of financiers and industrialists were preparing to support Roosevelt, Clarkson again typically explained their support in terms of conspiracy. The management of the Parker campaign by the Belmont brothers was, according to the old politician, "so clearly an invasion of English bankers that it frightened many of the American bankers, many of whom were alientated from Roosevelt, and brought them home." 15

Roosevelt reinforced Clarkson's predilections for a conspiracy theory in several ways. In addition to acknowledging its validity he welcomed the surveyor's personal friend, millionaire Leigh Hunt. Clarkson had first known Hunt as principal of East High School in Des moines and president of the State Agricultural College of Iowa, and he later became a business associate. Hunt was also recommended to Roosevelt by Nicholas Murray Butler, the

${ }^{14}$ Clarkson to Hunt, Oct. 19, 1903, Clarkson Papers, LC.

is Clarkson to Hunt, Oct. 9, 19, Nov. 17, 1903, April 7, Oct. 1, 1904, Clarkson Papers, LC: Clarkson to Loeb, April 25, 1904, Roosevelt Papers, LC. August Belmont migrated from Frankfurt in 1837 to become the American representative of the Rothschild banking interests. After his death in 1890 his sons, Perry and August, continued the family investiment-banking firm of August Belmont \& Co. and dabbled in Democratic party politics. 
president of Columbia University. ${ }^{16}$ Hunt was eager to contribute a sum of his great wealth to Roosevelt's cause, and the President was not unreceptive. He was also genuinely fascinated by Hunt's African adventures and interested in his experienced opinion on international imperialism. To Clarkson was left the task of dealing with the millionaire's political eccentricities, which required no little skill. Though he declined to have his name placed on the ballot as a nominee for vice-president on the Republican ticket, Hunt was persuaded by Clarkson that the party would need an occasional bank draft. Both Clarkson and Butler treated Hunt delicately, fully aware that he was "in a position to influence both the opinions and the pocketbooks of a number of men on Wall Street." "'

When Clarkson was not worrying about conspiracies of businessmen, he was fretting over combinations of labor. The President clearly desired his appointee to concern himself with rallying labor support behind the proper standard, and the old spoilsman performed the task dutifully in the only manner he knewthrough patronage. So successful was he that in January 1903 the Civil Service Commission censured him. ${ }^{18}$ As a consequence, the administration severely restricted Clarkson's appointive authority. He complained that it was "pretty hard to offer the place of a laborer to a man whom you expect to lead in the conquest of a district." 19 Secretary of the Treasury and former Iowa Governor Leslie M. Shaw responded. What Clarkson asked was "clear in the sky," replied Shaw, "and there are few positions up there." ${ }^{20}$

${ }^{16}$ Roosevelt to Joseph B. Bishop, Oct. 2, 1903, Morison, Letters, III, p. 609; Roosevelt to Clarkson, May 27, 1903, Clarkson to Loeb, June 3, 8, 1903, Howard $\mathrm{K}$. Beale, Theodore Roosevelt and the Rise of America to World Power (Baltimore, 1956), pp. 164-166. Nicholas Murray Butler was president of Columbia University from 1902-1945. With a well-developed concept of his own worth and his own idea of progressive Republicanism, Butler liked to believe that his close advisory relationship to Roosevelt was indespensible. Roosevelt used Butler as a sounding board and to make personal contacts, but often ignored the educator's advice.

'Roosevelt to Clarkson, Feb. 11, 1903 (enclosure), Clarkson to Roosevelt, May 11, 1904, Butler to Roosevelt, May 19, 1904 (quote), Roosevelt Papers, LC; Hunt to Clarkson, May 31, 1904, Clarkson Papers, IDHA.

${ }^{18}$ Roosevelt to Clarkson, Jan 3, March 30, 1903, Clarkson to Roosevelt, Feb. 4, 1903, John N. Parsons to Clarkson, July 14, 1903, Clarkson to Loeb, Sept. 29, 1903, Roosevelt Papers, LC.

${ }^{19}$ Clarkson to Leslie M. Shaw, Aug. 11, 1904, Clarkson Papers, IDHA.

${ }^{20}$ Shaw to Clarkson, Aug. 16, 1904, Clarkson Papers, IDHA. 
With labor, as with the financiers, Clarkson discovered conspiracies at work. Undercover plots were especially prevalent in the Postal Department he decided, and Roosevelt was inclined to see them, too. The apparent organization of the Letter Carriers Union behind the presidential candidacy of William Randolph Hearst, whom Clarkson automatically categorized as a socialist, was particularly ominous. On his own initiative Clarkson enlisted the aid of one F. G. R. Gordon, professional disrupter of nondemocratic meetings and "a deadly parasite to socialism," to divide and conquer pro-Hearst labor conventions in Massachusetts and Colorado. ${ }^{2 s}$

When eight of the state conventions of the Letter Carriers passed resolutions in 1903 commendatory to Hearst, Clarkson was pressed to the point of urging reinstituting the Hanna techniques of 1895 and 1896 , placing "in all these large labor national conventions some influential friends to checkmate the programme of the oppostion. . . ."22 Roosevelt responded to Clarkson's letter by ordering Postmaster-General Payne to "look into the alleged situation" and to remove "at once" any employee found to be organizing for Hearst. "People in the classified [civil] service are not allowed to . . . take offensive political action for the President," commanded the former Civil Service Commissioner, "and they certainly shall not do so against the President." ${ }^{23}$

An associate advised Clarkson that the labor situation could "be changed by work and tact." Clarkson provided the work, but Roosevelt displayed less than the necessary tact. In May 1903 the chief of the Government Printing Office, an old friend and associate of Clarkson, dismissed an employee because he had been expelled from the union. Roosevelt castigated the dismissal as an attempt to establish a union shop and demanded the reinstatement of the employee. Motivated by both personal loyalty and political reality, Clarkson came to the aid of his friend and the union. He feared most a general strike that would unite labor, especially the Letter Carriers Union, behind Hearst and "be a

${ }^{21}$ Parson to Clarkson, July 14, 1903, Roosevelt to Henry Clay Payne, July 16 , 1903, Clarkson to Roosevelt, June 3, 1903, F. G. R. Gordon to Clarkson, July 1, 8, 1903, C. A. Sulloway to Clarkson, July 8, 1903, Roosevelt Papers, LC.

${ }^{22}$ Clarkson to B. F. Barnes (enclosure), July 15, 1903, Roosevelt Papers, LC.

${ }^{23}$ Roosevelt to Payne, July 16, 1903, Roosevelt Papers, LC. 
great aid to the democrats. . ." But Roosevelt saw a conspiracy that was, for once, not visible to the surveyor, and he replied in bold words, "If those labor union men strike not one man jack of them will do another stroke of government work while I am President." ${ }^{24}$ Clarkson's only consolation was that Roosevelt's actions gained the approval and active support of the National Association of Manufacturers, who reported directly to the surveyor when it met in New York. Little enough comfort it was. ${ }^{25}$

Clarkson was most successful in organizing the different ethnic groups of New York City, with whom the President had previous experience and whose voting strength was soundly appreciated. The surveyor participated significantly in establishing an intimate working relationship with the president of the Hungarian Republican Club, for whom he recommended re-establishing the position of superintendent of immigration at the port. Clarkson pressed for "Special agents of the Treasury Department, men who speak and write several languages and who would make excellent interpreters, also men fitted for positions as laborers. . . ." Shortly before the 1904 general election Roosevelt completed his appeal by extending an invitation to the Hungarian Club officals to visit him at the White House. ${ }^{26}$

To Clarkson, the President's receptiveness to active organization among the ethnic communities contrasted refreshingly with the pacificism of some of his predecessors, who had thought that they had "gone too high to help in such earthly matters." 27 In addition to the Hungarians, the surveyor was busily organizing the more heterogeneous groups of Catholics and Jews. In 1902 Secretary of State John Hay gently suggested to the Czar that more leniency should be applied to the Jews in Russia and Rumania. In October, Clarkson requested that the Secretary make a speech at "one or two meetings on the lower East Side." $\mathrm{He}$ again received a warm and positive response from Roosevelt. ${ }^{28}$

${ }^{24}$ Roosevelt to Clarkson, July 16, 1903, Roosevelt Papers, LC.

${ }^{25}$ O. J. Ricketts to Clarkson, Sept. 17, 1903, Clarkson to Barnes, July 16, 1903, Clarkson to Roosevelt, July 29, 1903, Roosevelt Papers, LC; Roosevelt to Cortelyou, July 13, 1903, Morison, Letters, III, pp. 519, 514-515 (editor's note); Clarkson to Allison, Nov. 29, 1904, Allison Papers, IDHA.

${ }^{26}$ Marcus Braun to Clarkson, Aug. 4, 1902, Roosevelt Papers, LC.

${ }^{27}$ James S. Clarkson to Loeb, Oct. 20, 1902, Roosevelt Papers, LC.

${ }^{28}$ Blum, Roosevelt, pp. 15, 37, 63, 65; Roosevelt to Stranahan, April 25, 1902, Roosevelt to Eugene A. Philpin, July 16, 1902, Clarkson to Roosevelt, Aug. 
The Hungarian Club represented a large group of naturalized citizens, but the old campaigner was also interested in organizing immigrants as they first stepped off the boats. In June 1904 he complained of the "inability of the two United States Courts here to naturalize over nineteen or twenty men a day" and suggested an increase in the work force of the Naturalization Bureau to complement his efforts in Republicanization. Although the President did not explicitly agree to Clarkson's maneuvers, neither did he oppose them, and the surveyor was allowed to continue educating immigrants in the Republican gospel. ${ }^{29}$

Considering Clarkson's extensive efforts organizing the ethnic communities of New York, his reaction to George Bruce Cortelyou, chairman of the Republican National Committee, is somewhat puzzling. "There is nothing like getting the individual voter to work," the surveyor later wrote,

and then having the reserve organization to get out the vote. That and articles and letters well written appealing to the voter and his pride as a citizen, is more effective than surface work of any kind. ${ }^{30}$

In 1904 Cortelyou executed just that sort of campaign, and Clarkson was somewhat startled. To an old Republican raised on the personal politics of vitriolic journalism and rousing stump speeches, the subtle organization of Cortelyou appeared almost obscure. Although expressing complete confidence in the chairman, the former Republican vice-chairman noted that "just as . . all other kinds of business have been revolutionized and conducted on entirely new methods, so is Cortelyou ... . revolutionizing the system of politics and of campaigning." "The brass band has departed," and James S. Clarkson enjoyed the politics of the brass band. ${ }^{31}$

Clarkson had in the past contributed significantly to a new

6, 11, 1902, Robert E. Ford to Clarkson, Aug. 11, 1902, Roosevelt to Clarkson, Aug. 12, 1902, Aug. 16, 1904, Braun to Clarkson, Oct. 15, 1902, Clarkson to Loeb, Oct. 16, 1902, Roosevelt Papers, LC; ATWH, Oct. 27, 1904.

${ }^{29}$ Roosevelt to Clarkson, Dec. 24, 1902, William Halpin to Clarkson, June

11, 1904, Clarkson to Barnes, June 14, 1904, Roosevelt Papers, LC.

${ }^{30}$ Clarkson to Dodge, April 14, 1908, Dodge Papers, IDHA.

${ }^{31}$ Clarkson to Loeb, Sept. 15, 1904, Roosevelt Papers, LC; Clarkson to Cortelyou, Nov. 11, 1904, George Bruce Cortelyou Papers, LC; Clarkson to Hunt, Oct. 1, 1904 (Quote), Clarkson Papers, LC. 
orientation in Republican campaign techniques. Richard Jensen has recently added a great deal to the understanding of that stylistic change and is correct in estimating Clarkson's role in it. ${ }^{32}$ Jensen argues that the "military style" of campaigning, in which "the election was conceived as a great battle pitting the strength of opposing armies and the genius of their generals," was replaced in the second Harrison campaign by the "merchandizing style," which emphasized the personal education of the electorate through circulating the party press, supplying capable speakers for the debate, and widely distributing appropriate speeches. ${ }^{33}$

As one of the founders of the National Republican League, a full-time advertising and educational force oriented toward young men and concentrating on locating, educating, and polling independent voters, Clarkson led the reorientation. He firmly believed in the power of the press and the rational presentation of the Republican faith to groups that had not before been reached. But Jensen fails to recognize that for Clarkson Republicanism remained a faith. If a purge of the moralists in the party was necessary to complete the institutionalization of the merchandizing style, as Jensen suggests, then Clarkson was probably purged. This may explain the decline of his influence under McKinley, whom Jensen recognized as the practitioner par excellence of merchandizing. Most important, Clarkson's continued conception of Republicanism as a moral cause in itself clouded his vision of the party in 1904. To him Republicanism was the issue. To Cortelyou, Roosevelt, and other campaign strategists the Republican party was a vehicle for many issues, and for a candidate. ${ }^{34}$

Clarkson was happy to see the reactivation of the National Republican League under Roosevelt. First organized in 1887 and once presided over by Clarkson, the League became an independent pro-Roosevelt movement between the quarrelling factions of New York and served as a rallying point for all of the President's forces elsewhere in the nation, particularly in the West. J. Hampton Moore, the new president of the League, consulted Clarkson

${ }^{32}$ Richard Jensen, The Winning of the Midwest: Social and Political Conflict, 1888-1891 (Chicago and London, 1971), Chapter Six, "From Battlefield to Marketplace: Transition in Electioneering Style."

${ }^{33}$ Ibid., pp. 164-165, 165-168.

${ }^{34} I$ bid. . pp. 171-173, 176-177; Platt, Autobiography, p. 495. 
on organizational matters and for personal references, but the scarred old veteran did not in any sense act as an official advisor to Moore or Roosevelt on League concerns. ${ }^{35}$ There is little evidence that he was actively involved in the organization of the League in the West, and no evidence that either he or the League were influential in Iowa. Instead, Secretary Shaw stumped the West, and the venerable Senator Allison, with no little skill, mediated between the factions of the lowa Republican party.

The party division in Iowa involved both issues and personalities, which were brought to focus on Albert Baird Cummins. After ten years of political frustration, Cummins lowered his sights from the Senate and was elected Governor in 1901. The party platform included, by unanimous approval of the convention, a plank requesting "any modifications of the tariff schedules that may be required to prevent their affording a shelter to monopoly." According to the author of the "shelter plank" its intention was "not so much the destruction of monopoly as the protection of society from the evils of monopoly." The tariff was to be amended "from time to time" so that "no monopoly would have opportunity under it to make illegitimate gains." ${ }^{36}$

The intent "to be a liberalizing one upon the party, without proposing sudden or revolutionary changes" was later drastically altered by Cummins, who inextricably united the concepts of protection and monopoly. "[T]he Consumer," he thundered, "has a better right to competition than the producer has to protection." ${ }^{37}$ As a result of the "Iowa idea," as Cummins' formula for the destruction of trusts through revision of the tariff became known, the traditional factional struggle in Iowa was raised from the level of vituperative personal abuse, upon which it normally rested, to that of a national issue, a level which Roosevelt did not appreciate when it involved the tariff. ${ }^{38}$

${ }^{35}$ Wheaton, "Genius," pp. 192-194; J. Hampton Moore, Roosevelt and the Old Guard (Philadelphia, 1925), pp. 57-58, 77-80, 82-84, 90; John A. Stewart to Roosevelt, Dec. 16, 1902, Roosevelt Papers, LC.

${ }^{36}$ George Evan Roberts, "The Origins of the Iowa Idea," Iowa Journal of History and Politics, 2:69-70, 76. For a discussion of Iowa politics at this time, see: Ralph Mills Sayre, "Albert Baird Cummins and the Progressive Movement in Iowa" (unpublished Ph.D. dissertation, Columbia University, 1958), chapters V, VI.

${ }^{37}$ Roberts, "Idea," pp. 71, 74-75.

${ }^{38}$ Roosevelt to John Hay, Sept. 18, 1902, Morison, Letters, pp. 326-327; Roo- 
Clarkson had altered his ideas on revision since living in the East and thought that the "Iowa idea" had been "sounded none too soon." The President, on the other hand, argued that the position of the "shelter plank" was as ridiculous as the position of standing pat on protection, "and either would bring disaster." $\mathrm{He}$ feared that the Cummins' program would further alienate businessmen from the Administration and cause an unseemly show of disunity with a fight over the platform at the 1904 national convention. Theodore Roosevelt fully intended that the issue in the 1904 campaign would be Theodore Roosevelt. The "Iowa idea" seriously threatened that intention. ${ }^{39}$

Clarkson's most significant contribution in Iowa was the transferral of the ownership of the Des Moines Register, which he had in the 1870 s personally shaped into the state's major newspaper, and whose crusading tradition had been continued, if somewhat muted, under his brother's editorship. The ownership of newspapers was of no little consequence to Clarkson. He was as thoroughly convinced of the power of the press as he was of the opposition-Democratic conspiracy to control it. In June 1902, he successfully negotiated the sale of the Register to George E. Roberts, former Fort Dodge, Iowa editor, close friend of Senator Dolliver, and Director of the Mint in Washington. Although Clarkson felt that the new ownership was a strong one and would succeed, in only one year the paper was again sold, this time to interests not entirely in sympathy with the former editor. The transferral of the paper for the last time in 1903 signified the end of an era in Iowa politics and the end of any significant influence by "Ret" Clarkson in the political affairs of the state. ${ }^{40}$

The long struggle continued between Governor Cummins and

sevelt to Henry Cabot Lodge, April 27, 1903, Roosevelt to Allison, May 19, 1903, Roosevelt Papers, LC.

${ }^{39}$ Clarkson to Perkins, Aug. 13, 1902, Perkins Papers, IDHA; Roosevelt to Clarkson, May 27, 1903, Roosevelt to Lodge, April 27, 1903, Roosevelt Papers, LC. For a history of the "Iowa Idea" and its significance in Iowa state politics, see: James E. Diestler, "The Iowa Idea: Its Origins and Early Development" (unpublished M.A. thesis, Drake University, 1968).

"Springfield Republican, May 24, 1890; Clarkson to Cortelyou, Dec. 26, 1902, Clarkson to Loeb, Dec. 27, 1902, Roosevelt Papers, LC: Clarkson to Dodge, Nov. 28, 1903, Dodge Papers, IDHA; Clarkson to Allison, May 20, 1902, Allison Papers, IDHA; Clarkson to Perkins, July 8, 1902, Perkins Papers, IDHA; Sayre, "Cummins," pp. 212-213. 
Joseph W. Blythe, general counsel of the Chicago, Burlington, and Quincy Railroad and political sachem of southern Iowa. The "shelter plank" remained in the 1902 state platform, but as the July 1903 state convention neared, Roosevelt became increasingly apprehensive that a radical statement by Iowa Republicans relating the tariff to the trusts would reflect directly upon his administration. Interceding directly, he conferred with Cummins at the White House and directed Allison to mediate compromise tariff and trust planks with the antagonists. The result was a 1903 Iowa Republican platform of which "soothing sirup to a crying baby will not be a comparison. . . ." 41

Although J. W. Blythe understood that "the result of the [1903] election seems to indicate that the harmony business was not such a bad mistake after all," Cummins had entertained all the harmony he desired. In 1904 Roosevelt again conferred with the governor and once more pressed Allison into service, but Cummins remained insistent that both the state and national Republican parties should take resolute stands against tariffs that protected the trusts. He carried his demand to the national convention in Chicago, as Roosevelt was afraid he would, but was soundly rejected by his own delegation. The defeat of Cummins' demands for immediate tariff revision was a solid victory for Roosevelt. ${ }^{42}$

The election of Theodore Roosevelt in 1904 successfully concluded three years of political maneuvering and almost constant campaigning. The victory was complete and personal. But the overwhelming popular mandate was much more reassuring than that of the party politicians. In a careful study of the election, James Otis Wheaton concluded that Roosevelt was an exceptional popular politician but a less than adequate party manipulator. "An interest and ability for dealing with large voting segments," concludes Wheaton, "is different from an interest and ability for manipulating political machinery." Roosevelt was brilliant at the former, but bored with the latter. ${ }^{43}$

The Clarkson-Roosevelt relationship reveals much about Roo-

"Roberts, "Idea," pp. 77, 78-79; Cummins to Perkins, April 7, 1903, Allison to Cummins, April 16, 1903, Albert Baird Cummins Papers, IDHA; ATWH, Feb. 20, June 23, 1903.

${ }^{42}$ J. W. Blythe to Perkins, Nov. 9, 1903, Perkins Papers, IDHA.

${ }^{43}$ Wheaton, "Genius," p. 461. 
sevelt as both popular and party politician. In the South the President used a flexible appointive policy, often against Clarkson's moralistic advice, to establish viable political organizations in each state. He did not take a moral position either for or against those Republicans who wanted to exclude blacks from the party. The moral arguments did not concern him. The political results did. In explaining his failure to back the Republican integrationists in Louisiana, Roosevelt wrote Booker T. Washington simply that it was "preposteous in Louisana to back the same old Republican gang which [had] made the Republican party a byword" for years. ${ }^{44}$

Roosevelt was less successful with the political machines in the North. The Platt-Odell arrangement never worked well, and even the intervention of the venerable Senator Allison could not end the political fratricide in Iowa. But Roosevelt was irresistible to the people. His continued refusal to equivocate on the appointment of a black man as collector of the port of Charleston helped solidify northern blacks. Clarkson's work with the laborers and ethnics exemplified the type of personal organization and appeal that, multiplied by thousands, comprised the Roosevelt campaign and persuaded the voters of his irresistibility. But the appeal was too personal for many of the old party leaders. It did not need them, and thus depreciated their sense of worth, which had been highly developed over half a century. Roosevelt proved uncanny at dealing with "popular aspirations, interests, fears, and anxieties" and poor at dealing with "the aims of a small group of professional organizers whose objects or emotions are not necessarily close to those of their constituents." 45

From early 1903 through the election, James S. Clarkson quietly organized laborers and ethnic groups, wrote noticeably fewer letters soliciting the President's efforts on behalf of Negro civil rights, and made occasional trips west to visit his ill brother and pneumonic son and to coincidentally test the political climate. He also continued to provide political intelligence to the President, much of it involving plots or the threat of plots, some of it valuable. Again, in New York, Clarkson was denied the privilege of representing the President in the upper echelons of the

\footnotetext{
"Roosevelt to Washington, June 8, 1904, Roosevelt Papers, LC.

${ }^{45}$ Wheaton, "Genius," p. 461.
} 
Republican party. Instead, he organized the dock hands, religious groups, naturalized minorities, and the recently arrived. He proved good at his work, and he did not complain, but he desired more. Not even in Iowa, where "Ret" Clarkson had personified the Republican party for twenty years, did he retain any significant influence. He continued in the office of surveyor until 1910 , but by the election of 1904 the days of brass band politics had ended for James S. Clarkson.

\section{Museum Notes}

by John Phipps,

Museum Director

THE OLD ADAGE "everything comes to he who waits" is particularly true of museum collections. An example of this is our recent acquisition of a portrait of General Henry Atkinson painted by George Catlin.

Fort Atkinson, built in 1840 in Winneshiek County, Iowa was named in honor of the general. A fort built twenty years earlier in Nebraska was also named for Atkinson. The former garrison, it has been said, was the only military post ever founded to protect Indians from harrassment by other Indians.

George Catlin was a painter and student of ethnology. $\mathrm{He}$ was interested in people-especially Indians-their dress, cusfoms and way of life. His paintings of Indians made during travels throughout North America in the 1830s are priceless records of the native peoples of this continent. Likewise his portraits of well-known individuals are important artistically as well as historically.

The portrait of General Atkinson by George Catlin is now on display at the Historical Building in Des Moines. The State of Iowa is proud to have a genuine Catlin. 
Copyright of Annals of Iowa is the property of State of Iowa, by \& through the State Historical Society of Iowa and its content may not be copied or emailed to multiple sites or posted to a listserv without the copyright holder's express written permission. However, users may print, download, or email articles for individual use. 